\title{
Fenomenologi Pelaksanaan Upacara Ngaben (Pitra Yadnya) di Kota Mataram (Pendekatan Sosiologi Agama)
}

\author{
I Wayan Wirata \\ Institut Agama Hindu Negeri Gde Pudja Mataram \\ iwayanwirata372@gmail.com
}

\begin{abstract}
In the field of pitra yadnya, that the sacrificial ceremony is one of the obligations of Hindus that must be carried out, because it is considered to have noble values according to Vedic literature. The pitra yadnya ceremony has the meaning of paying debts to the ancestors who have given birth to mankind, so the pitra yadnya must be carried out by Hindus. But in reality, other people forbid the implementation of Ngaben (Pitra Yadnya) such as: burning corpses, using angklung gamelan facilities, and chanting kidung (wirama) because they are considered to interfere with their daily activities. This research is a qualitative research, which aims to describe and explain the meaning of sarcasm in dialect. Berg (2001) explains that qualitative research tries to answer questions by examining various social phenomena in a place and the individuals who live in that place. The data collection techniques which is used in this study are: 1) Observation by involving researchers in the daily activities of the object under study, in addition to the researcher being able to observe the object of research comprehensively; 2). Interviews with the aim of digging up information about the challenges of the pitra yadnya ceremony; and 3 ) Documentation is used in this study to find documents related to the phenomenological research on the implementation of pitra yadnya in Mataram City. The results of the research on the Hindu phenomenon in the implementation of the Ngaben ceremony (Pitra Yadnya) in Mataram City are as follows: domination of power, narrow religious understanding, lack of respect for local values and the impact of the phenomenon of carrying out the Ngaben ceremony (Pitra Yadnya) in Mataram City are as follows : the impact of culture, social, power, and justice.
\end{abstract}

Keywords: Phenomenology; Ngaben Ceremony

\begin{abstract}
Abstrak
Dalam bidang pitra yadnya, bahwa upacara korban suci merupakan salah satu kewajiban umat Hindu yang harus dilaksanakan, karena dianggap memiliki nilai luhur sesuai sastra Weda. Upacara pitra yadnya memiliki makna pembayaran hutang kepada leluhur yang telah melahirkan umat manusia, sehingga pitra yadnya harus dilaksanakan oleh umat Hindu. Namun realitanya umat lain melarang pelaksanaan Ngaben (Pitra Yadnya) seperti: pembakaran jenazah, penggunaan sarana gamelan angklung, dan melantunkan kidung (wirama) karena dianggap mengganggu aktivitasnya sehari-hari. Penelitian ini termasuk penelitian kualitatif yaitu bertujuan untuk menggambarkan dan menjelaskan makna ungkapan sarkasme dalam dialek. Berg (2001) menjelaskan bahwa penelitian kualitatif mencoba untuk menjawab pertanyaan-pertanyaan dengan menguji berbagai fenomena sosial di suatu tempat dan individu yang tinggal di tempat tersebut. Teknik pengumpulan data yang digunakan dalam penelitian ini yaitu: 1) Observasi dengan melibatkan peneliti dalam kegiatan sehari-hari dari objek yang diteliti, disamping peneliti dapat mengamati objek penelitian secara komprehensif; 2). Wawancara dengan tujuan menggali informasi mengenai tantangan upacara pitra yadnya; dan 3) Dokumentasi
\end{abstract}


digunakan dalam penelitian ini untuk mencari dokumen yang terkait dengan penelitian fenomenologi pelaksanaan pitra yadnya di Kota Mataram. Hasil penelitian tentang fenomena Hindu dalam pelaksanaan upacara ngaben (Pitra Yadnya) di Kota Mataram adalah sebagai berikut: dominasi kekuasaan, pemahaman agama sempit, kurang penghargaan tehadap nilai-nilai kelokalan serta dampak fenomena pelaksanaan upacara ngaben (Pitra Yadnya) di Kota Mataram adalah sebagai berikut: dampak budaya, sosial, kekuasaan, dan keadilan.

\section{Kata Kunci : Fenomenologi; Upacara Ngaben}

\section{Pendahuluan}

Kota Mataram merupakan suatu wilayah yang dihuni oleh berbagai berbagai suku, ras, budaya serta agama. Dengan pluralitas yang dimiliki diharapkan tercipta kehidupan yang harmonis menuju kesejahteraan lahir batin. Hal tersebut digunakan sebagai modal dasar dalam meningkatkan rasa persatuan dan pesaudaraan di antara umat beragama. Hal ini sesuai dengan pernyataan Digdoyo (2015: 163-164) menjelaskan bahwa perlunya saling menghargai diantara masyarakat majemuk. Dengan berpedoman iman (srada) dan taqwa (bhakti), maka masyarakat Kota Mataram dianggap sebagai masyarakat yang maju, religius, dan berbudaya.

Religiusitas iman (Srada) dan taqwa (Bhakti) kehidupan masyarakat Hindu Kota Mataram dapat diimplementasikan melalui pelaksanaan Panca Yadnya yang meliputi: Dewa Yadnya, Rsi Yadnya, Manusia Yadnya, Pitra Yadnya, dan Bhuta Yadnya. Salah satu panca yadnya terkait dengan pengembalian jasad menuju asalnya (Panca Mahabhuta) dalam upacara Panca Yadnya disebut upacara Ngaben (Pitra Yadnya).

Upacara Ngaben secara konsepsional meliputi tahapan sebagai berikut: 1) Pembakaran jenazah dilanjutkan menghanyutkan abu ke sungai, atau laut yang bermakna melepaskan Sang Atma (roh) dari belenggu keduniawian, sehingga mudah bersatu dengan Tuhan (Mokshatam Atmanam); 2) Membakar jenazah merupakan suatu rangkaian upacara mengembalikan unsur Panca Mahabhuta (lima unsur pembangun badan kasar manusia) kepada asalnya, sehingga tidak menghalangi perjalanan atma ke Sunia Loka; dan 3) Ketulusikhlasan keluarga yang meninggal kepada almarhum supaya cepat menyatu dengan Ida Sang Hyang Widhi Wasa. Dengan demikian dibutuhkan kesadaran masyarakat tentang arti pentingnya makna kehidupan, sehingga dapat melaksanakan swadharmanya dengan dengan sebaik-baiknya.

Umat Hindu dalam meningkatkan kualitas hidup beragama selalu melakukan pendekatan sosial religius dengan mengacu pada konsep gugon tuwon dengan perpedoman pada sastra agama. Hal tersebut sesuai dengan konsep Mulyana (2001: 20) menjelaskan bahwa diperlukan adanya komunikasi antara budaya untuk memahami suatu indentitas orang lain. Dengan demikian perlu disadari betapa pentingnya arti upacara agama, karena upacara merupakan implementasi dari Tri Kerangka Agama Hindu yaitu tattwa, susila, dan upacara. Adanya pemahaman mendalam tentang tattwa agama merupakan ciri utama masyarakat agamais berpedoman pada konsep sastra agama. Dengan demikian diperlukan jalan bhakti, sehingga membawa seseorang pada peningkatan kualitas diri baik secara material maupun spiritual. Sikap tulus ikhlas salah satu sikap religius umat Hindu dapat diwujudkan dalam sikap beryadnya. Hal tersebut dilakukan melalui berbuat kebajikan pada sesama dan taat pada kewajiban masing-masing. Hal senada dipertegas Wiana (2006: 30) menjelaskan bahwa beryadnya bukanlah berarti melakukan upacara agama belaka, namun berkorban secara tulus ikhlas dengan berbagai hal dengan niat suci dan tulus iklas seperti: bersedekah, belajar sastra agama, dan mengorbankan perasaan demi kepentingan bersama dan lain sebagainya. 
Yajña merupakan suatu korban suci secara tulus ikhlas, karena dalam konsep Hindu yakin bahwa setiap manusia lahiran ke dunia selalu terikat dengan hutang (Rna). Oleh sebab itu, wajib hukumnya bagi setiap umat Hindu untuk membayar hutang (Rna) dilakukan dengan Yajña. Hutang atau Rna yang diyakini umat Hindu dapat dibayar melalui Tri Rna. Hal ini sesuai dengan pendapat Soeka (1989: 11) menyatakan bahwa Tri Rnam berarti tiga macam hutang budi, yaitu: 1) Dewa Rnam yaitu hutang jiwa kepada Ida Hyang Widhi Wasa yang telah menciptakan dan menghidupkan manusia dengan segala isinya; 2) Pitra Rnam yaitu hutang hidup kepada leluhur terutama Ibu dan Bapak yang telah melahirkan dan membesarkan hingga dewasa; dan 3) Rsi Rnam yaitu hutang jasa kepada para Maha Rsi atau Guru yang telah berjasa dalam mengajarkan ilmu pengetahuan kerohanian, sehingga meningkatkan kualitas hidup suci baik secara lahiriah maupun batiniah.

Dalam bidang pitra yadnya, bahwa upacara korban suci merupakan salah satu kewajiban umat Hindu yang harus dilaksanakan, karena dianggap memiliki nilai luhur sesuai sastra Weda. Upacara pitra yadnya memiliki makna pembayaran hutang kepada leluhur yang telah melahirkan umat manusia, sehingga pitra yadnya harus dilaksanakan oleh umat Hindu. Namun realitanya umat lain melarang pelaksanaan Ngaben (Pitra Yadnya) seperti: pembakaran jenazah, penggunaan sarana gamelan angklung, dan melantunkan kidung (wirama) karena dianggap mengganggu aktivitasnya sehari-hari.

Dengan mencermati kondisi tersebut, maka terjadi kesenjangan antara harapan (das sollen) dan kenyataan (das sein) yaitu di satu sisi motto Kota Mataram yaitu: menjadikan Kota Mataram menjadi masyarakat yang maju, religius, dan berbudaya, di sisi lain pelaksanaan agama dan budaya yang digunakan sebagai landasan berperilaku religius dan berbudaya masyarakat justru dilarang bahkan dihambat. Dengan demikian terjadi fenomena yang berimplikasi melunturkan dan menghilangkan nilai-nilai agama dan budaya adi luhung umat Hindu. Namun, ketika terjadinya upacara Ngaben (pitra yadnya) oleh umat Hindu melalui pembakaran jenazah, penggunaan sarana gamelan angklung, suara kidung (wirama) dilakukan penekanan atau terjadi marginalisasi, sehingga menimbulkan fenomena sosial umat Hindu. Hal tersebut menyebabkan peneliti tertarik untuk mengkaji fenomenologi pelaksanaan upacara Ngaben (pitra yadnya) di Kota Mataram. Dengan demikian, peneliti memiliki pandangan baru tentang nilai-nilai agama dan budaya sebagai suatu identitas sosial justru didekontruksi secara sosial masyarakat Kota Mataram menjadi masyarakat maju, religius, dan berbudaya.

Dalam realitanya telah dirasakan adanya kesenjangan bahkan diskriminasi oleh umat Hindu di Kota Mataram. Upacara Ngaben (Pitra Yadnya) merupakan kewajiban umat Hindu untuk membayar hutang kepada leluhurnya. Ketika jenazah telah dibawa kekuburan untuk dibakar, ada penolakan oknum kepala sekolah untuk pembakaran mayat tersebut, karena dianggap mengganggu anak-anak sekolah, padahal kuburan tersebut lebih dahulu berdiri dibanding sekolah, sehingga umat Hindu merasa haknya dikebiri dan menimbulkan kekecewaan masyarakat Hindu.

Dalam bidang penggunaan gamelan angklung, pelarangan menyuarakan gamelan angklung, karena dianggap mengganggu ibadah shalat umat lain. Padahal jarak keberadaan tempat ibadah masjid dengan pelaksanaan cukup jauh, di samping itu pelarangan melantungkan kidung atau wirama karena dianggap mengganggu pelaksanaan aktivitas ibadah umat lainnya. Hal yang menjadi kontradiksi, ketika umat umat lain melaksanakan upacara pemakaman jenazah mereka menggunakan loudspeaker cukup keras, umat Hindu tidak merasa berkeberatan bahkan memaklumi adanya, namun ketika umat Hindu melaksanakan upacara agama yang berlandaskan nilai-nilai luhur ajaran kitab suci justru dilarang bahkan dianggap mengganggu ibadat shalat dan lain sebagainya. 


\section{Metode}

Penelitian ini termasuk penelitian kualitatif yaitu bertujuan untuk menggambarkan dan menjelaskan makna ungkapan sarkasme dalam dialek. Dalam penelitian kualitatif menjelaskan bahwa penelitian yang mencoba untuk menjawab pertanyaan-pertanyaan dengan menguji berbagai fenomena sosial di suatu tempat dan individu yang tinggal di tempat tersebut. Hal senada diungkapkan Mantra (2004: 27) menjelaskan bahwa alat pengumpulan data dalam penelitian kualitatif sesungguhnya peneliti itu sendiri, karena pemahamannya mendalam tentang objek yang diteliti.

Teknik pengumpulan data yang digunakan dalam penelitian ini yaitu yaitu : 1) Observasi merupakan pengumpulkan data dengan melibatkan peneliti terhadap objek yang diteliti. Dengan demikian peneliti mengamati objek secara komprehensif; 2). Wawancara digunakan untuk menggali informasi tentang tantangan upacara pitra yadnya; dan 3) Dokumentasi digunakan untuk mencari dokumen terkait dengan fenomenologi pelaksanaan pitra yadnya di Kota Mataram. Hal senada sesuai dengan pernyataan Sugiyono (2005: 137) menjelaskan bahwa wawancara digunakan apabila peneliti ingin melakukan studi pendahuluan untuk menentukan masalah yang harus diteliti.

Selain hal tersebut digunakan dokumen seperti buku, majalah, dokumen dan catatan harian sebagai dokumen (Arikunto, 2010: 201). Hal senada diperkuat oleh dokumen resmi termasuk keputusan dan surat bukti kegiatan yang digunakan sebagai informasi kuat dalam suatu bukti kejadian di lapangan (Darmadi, 2011: 266).

Pitra yadnya merupakan upacara penghormatan dan kewajiban suci ditujukan kepada para leluhur termasuk kepada orang tua yang telah meninggal dunia, sehingga diharapkan masih dapat terhubung dengan sanak keluarganya. Dengan adanya kelahiran, maka perhatian kita terhadap orang tua selalu dilakukan semasa hidup manusia, sehingga upacara pitra yadnya tetap dilakukan oleh parisentana atau keluarga batihnya. Dengan demikian, pitra yadnya dianggap sebagai kewajiban setiap umat Hindu yang harus dilakukan untuk membayar hutang (rnam) dengan leluhurnya.

Tujuan utama upacara pitra yadnya adalah sebagai proses pengembalian Panca Maha Bhuta Sang Amantuk, agar kembali ke sumbernya yakni Sang Hyang Prakerthi sebagai kekuatan "Acetana" dari Sang Hyang Widhi. Sedangkan penyucian atman (Rokh atau Arwah dari Sang Amantuk). Esensi sesungguhnya adalah lebih ditentukan oleh karma wasananya sendiri ketika ketika masih hidup di mercapada, alam bwah loka. adapun urutan upacara pitra yadnya yang dilakukan oleh preti sentananya (Putra Yang Su-Putra) adalah sebagai berikut:1) Sawa Wedana, pengeringkesan, pangaskaran dan ngaben; 2) Asti Wedana, dari ngereka sampai nganyut sekah; 3) Atma Wedana, dari ngangget don bingin sampai ngelinggihin dewa pitara: dan 4) Setelah meajar-ajar, maka selesailah seluruh rangkaian upacara pitra yadnya yang dilaksanakan.

Pada dasarnya seluruh urutan Pitra Yadnya tersebut dapat diringkas dengan upacara ngelanus yang dilaksanakan secara lebih efisien. Dengan demikian bagi keluarga yang ditinggalkan, bahwa tujuan upacara Pitra Yadnya dilaksanakan sebagaimana disebutkan babad Bali. Adapan jenis yadnya tersebut bertujuan untuk: 1) Pengabdian dan bakti yang tulus ikhlas; 2) Mengangkat serta menyempurnakan kedudukan arwah leluhur di alam sorga; swah loka; 3) Memperhatikan kepentingan orang tua dengan jalan mewujudkan rasa bakti; dan 4) Memberikan sesuatu yang baik dan layak, menghormati serta merawat hidup di hari tuanya juga termasuk pelaksanaan upacara yadnya yang selalu didasari dengan rasa tulus ikhlas.

Hal tersebut dilaksanakan atas kesadaran bahwa sebagai keluarga yang ditinggalkan oleh keturunannya telah berhutang kepada orang tuanya (leluhur) seperti: 1) Kita berhutang badan (sarira kosha) yang disebut dengan istilah Sarirakrit; 2) Kita 
berhutang budi yang disebut dengan istilah Anadatha; dan 3) Kita berhutang jiwa yang disebut dengan istilah Pranadatha.

Upacara pitra yadnya ini juga disebutkan didasari atas hukum sebab akibat dari karma phala, sebagai keyakinan adanya Punarbhawa dan kita percaya leluhur itu masih hidup di dunia atau alam semesta ini, dalam alam yang lebih halus. Pada dasarnya terdapat empat lontar utama yang memberikan petunjuk tentang upacara yadnya ini yaitu:

1. Lontar Yama Purwa Tatwa (mengenai tetandingan sesajen yang digunakan dalam upacara pitra yadnya), bentuk-bentuk bangunan petulangan, tri aksara kajang, dan sarana upacaranya.

2. Lontar Yama Purana Tatwa (mengenai filsafat pembebasan/Lontar Kamoksan atau pencarian atma dan hari baik-buruk (ala ayuning dewasa) melaksanakan upacara.

3. Lontar Yama Purwana Tatwa (mengenai susunan acara dan bentuk rerajahan kajang) serta kelengkapannya.

Demikian juga dalam persembahan upacara pitra yadnya yang tertuang dalam lontar putru pasaji, karena banyak jenis ikan yang dapat dijadikan persembahan kepada sang pitara. Dengan demikian kesenangan yang dapat diberikan oleh masingmasing ikan berbeda dalam persembahan kepada pitra. Adapun persembahannya adalah sebagai berikut: 1) Ikan laut kualitasnya paling rendah karena dapat memberikan kesenangan hanya selama satu bulan; dan 2) Sedangkan ikan/daging yang kualitasnya tertinggi adalah badak, karena akan dapat memberikan kesenangan selamanya di sorga. Dalam penentuan upacara pitra yadnya tentang hari baik dan buruknya upacara dapat dilakukan sebagai berikut:

1. Tentang penentuan hari baik dan buruk (padewasan) yang berhubungan dengan Pitra Yadnya ini banyak disebutkan dalam lontar aji swamandala, seperti larangan melakukan upacara pitra yadnya ini pada saat tumpek.

2. Dokumen Pura Kawitan, Pitra Yajnya 2000, khususnya buat kita Umat Hindu disebutkan beberapa istilah seperti :

3. Pegat Angkihan, tujuan doa pralina agar roh berjalan tenang dan diterima oleh Ida Sang Hyang Wenang/Hyang Widhi dan dapat mencapai kesucian.

4. Angenan merupakan simbolisasi dari pada batin atau jiwa sang atma yang diletakkan di atas pelengkungan tempat jenasah.

5. Bubur pirata hendaknya juga dilengkapi dengan empehan atau susu.

6. Tetandingan Banten Papegat, sampiyanya disebutkan dilengkapi dengan 2 buah sesampiyan pusung dengan gantung-gantungan.

7. Perlengkapan Upacara Pitra Yadnya yang dibutuhkan disesuaikan dengan kemampuan sesuai dengan Desa, Kala, Patra dengan tingkatan-tingkatan Tri Mandala dalam bentuk nista, madya, dan utama seperti halnya dalam pembuatan tetukon, karena bahan-bahan dari kelengkapannya sangat membutuhkan waktu untuk mencarinya.

Selain itu kidung yang digunakan untuk acara pitra yadnya yaitu Aji Kembang yaitu kidung pitra yadnya disebutkan dilantunkan pada saat wawu seda, nangunin, dan nyiramin layon. Dalam tradisi warisan nenek moyang, upacara ngunye yang dilakukan saat upacara pitra yadnya ditujukan untuk memberikan kesempatan terakhir bagi krama Banjar untuk dapat ngampurayang/memaafkan sang pitra jika ada kesalahan/kekeliruan yang diperbuat terhadap krama dan belum dimaafkan hingga dibawa mati.

\section{Pembahasan}

\section{Fenomenologi Pelaksanaan Upacara Ngaben (Pitra Yadnya) di Kota Mataram} Fenomenologi Umat Hindu dalam Pelaksanaan Upacara Ngaben (Pitra Yadnya) di Kota Mataram dalam realitanya adalah sebagai berikut: 


\section{a. Pelaksanaan Pembuangan Abu}

Upacara ngaben merupakan upacara yang dilakukan dalam rangka menebus atau membayar hutang terhadap leluhur. Dalam ajaran agama Hindu bahwa hutang yang diterima manusia harus dibayar sesuai dengan karmanya masing-masing. Dengan demikian bahwa pembayaran hutang dilakukan dalam rangka meningkatkan kualitas hidup umat Hindu. Upacara pitra yadnya bertujuan menebus segala dosa dan kesalahan yang dilakukan selama manusia melakukan segala aktivitas di dunia ini.

Upacara ngaben dilakukan melalui proses yang dilakukan umat Hindu di Kota Mataram dalam rangka meningkatkan eksistensi umat Hindu dalam aktivitas ritual umat Hindu. Pada dasarya upacara ngaben dilakukan untuk mengembalikan unsur panca maha buta melalui pembuangan abu ke pantai. Pada dasarnya membuang abu ke laut atau ke pantai dianggap dekat dengan tempat tinggalnya. Dengan demikian tercipta harmonisasi unsur panca mahabuta kepada asalnya. Untuk itu tercipta tatanan kehidupan yang selaras, serasi, dan seimbang untuk menuju ke alam yang sebenarnya.

Dalam melaksanakan kegiatan upacara membuang abu, Umat Hindu menggunakan pantai-pantai atau laut yang dianggap dekat dengan tempat tinggalnya. Pada umumnya umat Hindu membuang abu dilakukan menggunakan kendaraan, atau kelengkapan lain, dan bunyi-bunyian berupa gong, angklung atau tetabuhan lain yang dianggap memiliki fungsi dan sasaran yang sama terhadap makna kelengkapan upacara pitra yadnya/ngaben. Dalam realitasnya, ketika pelaksanaan membuang di pantai, tiba-tiba tempat pelaksanaan pembuangan abu di tempat tersebut ditutup, bahkan dilarang karena digunakan tempat menaruh sampan sehingga umat Hindu mendapat hambatan atau tidak diperkenankan membuang abu wilayah tersebut. Hal ini sesuai dengan pendapat Kuswarno (2013: 109) menjelaskan bahwa tindakan sosial terjadi dengan mempertimbangkan perilaku orang lain dan berorientasi pada perilaku manusia yang mempunyai makna subyektif bagi perilakunya. Dengan demikian diharapkan adanya komunikasi dan interaksi yang komunikatif dengan masyarakat setempat, namun masyarakat setempat tetap menolak dengan alasan bahwa tempat tersebut dipenuhi oleh sampan nelayan, sehingga menghambat proses membuang abu di wilayah Tanjung Karang, sehingga pindah ke wilayah Loang Balok.

Dengan melihat informasi tersebut, bahwa umat Hindu merasakan ada fenomena sosial terhadap eksistensi umat Hindu. Hal ini menyebabkan terjadi perlakuan kurang adil terhadap hak dalam menggunakan lingkungan untuk melaksanakan kegiatan ritual. Hal ini berimplikasi terhadap kerukunan umat beragama di Kota Mataram. Hal tersebut sesuai dengan pendapat Sutrisno (2005: 178) menjelaskan bahwa wilayah bidang sosial sebagai tempat pelaku berusaha untuk memperoleh kekuasaan dan status.

\section{b. Bunyi-Bunyian Anglung, Gong, dan Gender}

Pelaksanaan upacara pitra yadnya atau ngaben pada dasarnya kelihatan meriah serta hidmat, bila pelaksanaan upacara dilengkapai dengan bunyi-bunyian. Hal inilah menjadi atribut dan identitas sebagai bagian yang tidak terpisahkan satu dengan yang lainnya. Di samping adanya peningkatan ketulusikhlasan umat Hindu dalam meningkatkan kualitas umat beragama di Kota Mataram. Adanya partisipasi masyarakat dalam memeriahkan upacara yadnya, diperlukan kemasan atau formulasi upacara yang diadaptasikan dengan kelengkapan instrumen-intrumen yang dimiliki umat Hindu. Instrumen-instrumen tersebut dapat meningkatkan kemeriahan dan kemegahan upacara yadnya, sehingga dilakukan upaya dalam rangka mempertahankan eksistensi umat beragama di Kota Mataram. Dalam agama Hindu, upacara korban suci sering disebut dengan istilah yadnya yang merupakan bagian dari dharma. Upacara yadnya merupakan unsur keimanan yang penting bagi masyarakat dalam rangka meningkatkan nilai-nilai 
kemanusiaan dan religiusitas umat Hindu. Pitra yadnya adalah salah satu dari lima ajaran yadnya disebut panca yadnya. Dengan demikian pitra yadnya merupakan suatu rangkaian upacara yang digunakan untuk memuliakan leluhur yang telah meninggal. Pada umumnya upacara pitra yadnya dibagi menjadi dua tahap, yaitu 1) mengembalikan unsur jasmani kepada asalnya yaitu panca maha bhuta yang ada di alam semesta disebut dengan sawa wedana yang pada umumnya di Bali sering disebut dengan upacara ngaben; serta 2) menghantarkan atma (roh) untuk dapat sampai ke tempat yang lebih tinggi atau lebih baik yang disebut dengan atma wedana atau nyekah.

Dalam kitab-kitab suci agama Hindu tujuan yadnya adalah untuk memperoleh kebenaran yang mendasar, yaitu menemukan makna hakiki dan makna ajaran agama salah satunya dapat diimplementasikan dalam upacara pitra yadnya. Tujuan dari pitra yadnya sendiri pada intinya adalah agar para leluhur mendapat surga dan kelepasan. Upacara pitra yadnya dilakukan untuk membayar hutang terhadap leluhur yang menjadi asal mula atau perantara manusia dilahirkan ke dunia. Dengan demikian masyarakat telah meyakini jika upacara pitra yadnya tidak dilaksanakan, maka jiwa orang yang meninggal tetap berada di alam maya serta mendatangkan bahaya bagi manusia. Dengan demikian upacara pitra yadnya sepatutnya tetap dilaksanakan bagi umat Hindu dalam rangka menyeimbangkan alam semesta beserta isinya. Hal tersebut sesuai dengan pernyataan Amin (1997: 115) menjelaskan bahwa budaya masayarakat disekitarnya diperlukan adanya persamaan seperti system kepercayaan, adat istiadat, dan kesenian.

Dalam pelaksanaan pitra yadnya bunyi-bunyian digunakan untuk menunjang pelaksanaan upacara pitra yadnya, maka diperlukan instrumen dalam bentuk bunyibunyian seperti gong, angklung, dan gender sebagai bagian kelengkapan pelaksanaan proses upacara ngaben di Kota Mataram. Instrumen angklung, gong, dan gender digunakan sebagai bagian dalam meningkatkan kualitas upacara bagi masyarakat Hindu di Kota Mataram. Untuk itu perlu adanya kemasan sesuai dengan kebutuhan masyarakat Hindu Kota Mataram. Dengan adanya angklung, gong atau gender yang dibunyikan pada saat pelaksanaan upacara menimbulkan ketegangan sosial yang dianggap mengganggu ketenteraman dan kenyamanan masyarakat lingkungan sekitarnya dalam melaksanakan upacara sembahyang. Dengan hal tersebut umat Hindu merasa haknya dikebiri sebagai warga negara dan warga masyarakat yang adil dan memiliki kearifan lokal. Hal tersebut menimbulkan ketegangan sosial masyarakat sehingga mengganggu kenyamanan dan keamanan masyarakat Hindu di Kota Mataram.

Dengan demikian diperlukan pendekatan edukatif dan persuasif yang terpusat dalam rangka meningkatkan kapabilitas umat Hindu untuk mempertahankan dan melestarikan keberadaan eksistensi ritual umat Hindu di Kota Mataram. Dalam melaksanakan kegiatan dimaksud perlu adanya kesepakatan bersama dalam rangka mendukung serta mempertahankan upacara ngaben di Kota Mataram. Untuk meningkatkan aksesbilitas dan kualitas umat Hindu di Kota Mataram dalam melestarikan dan mempertahankan upacara agama, maka dibutuhkan kemasan sesuai dengan dengan konsep desa (tempat), kala (waktu), dan patra (keadaan). Hal inilah dapat menunjang pelaksanaan upacara ngaben secara efesien, efektif, dan kondusif. Dengan demikian dapat meningkatkan rasa kebersamaan dan persaudaraan di antara umat Hindu di Kota Mataram.

Dalam kelengkapan upacara ngaben (pitra yadnya) pada umumnya menggunakan kelengkapan gamelan gong, angklung, dan gender. Dalam realitanya upacara tersebut dapat berjalan dengan sakral dan suci bila dilengkapi dengan gamelan gender dan angklung. Hal tersebutlah menciptakan nuansa ritual yang magis dalam melaksanakan upacara ngaben. Untuk dapat memeriahkan upacara tersebut diperlukan kelengkapan yang dapat memberikan nuansa sakral dan hidmat. Namun dalam kenyataannya, bila menggunakan angklung, gong, dan gender, tiba-tiba disuruh berhenti oleh masyarakat 
tetangga, karena dianggap mengganggu pelaksanaan sholat. Inilah yang menyebabkan masyarakat Hindu kecewa. Dengan demikian umat Hindu merasakan adanya perlakuan kurang adil dalam konsep kerukunan umat beragama di Kota Mataram.

\section{c. Penggunaan Loud Speaker Bunyi Dharma Gita}

Upacara dalam umat Hindu selalu mengacu pada konsep desa mawa cara atau desa kala patra. Hal inilah sebagai adagium pelestarian kearifan lokal umat Hindu di Kota Mataram. Hal inilah menciptakan kerukunan atau toleransi umat beragama di Kota Mataram sesuai dengan yang diharapkan bersama. Upacara ngaben dapat dilaksanakan secara hidmat, bilamana upacara ngaben diiringi atau dilengkapi dengan pembacaan dan pelafalan kidung atau wirama kemudian dengan melantungkan nyanyian-nyanyian keagamaan meningkatkan kemegahan dan kemeriahan estetika pelaksanaan upacara ngaben. Hal ini sesuai dengan pernyataan Koentjaraningrat (2002: 114-115) menjelaskan bahwa kebudayaan merupakan upaya pengembangan aktivitas dan kreatifitas masayarakat serta dalam praktek-praktek nilai seni. Pelantunan Dharma Gita diekspersikan dalam upacara ngaben dalam rangka meningkatkan keragaman dan rasa kebersamaan di antara umat beragama di Kota Mataram. Setiap pelaksanaan upacara keagamaan harus diikuti dengan lantunan seni-seni keagamaan melalui Dharma Gita. Dharma Gita yang dibaca meliputi, arjuna wiwaha, brata yudha, aji palayon dan lontar-lontar yang lainnya. Hal senada sesuai dengan konsep Djelatik (1999: 9) menjelaskan bahwa estetika mempelajari tentang segala sesuatu yang berkaitan dengan keindahan.

Pelapalan dan ekspresi Dharma Gita yang diekspresikan dapat meningkatkan peran serta dan partisipasi masyarakat untuk menciptakan rasa kehidmatan dan keyakinan yang mendalam terhadap pengembangan dan penajaman serta kekhusukan upacara yadnya umat Hindu di Kota Mataram. Setiap pelafalan dilakukan selalu berorientasi pada nyanyian keagamaan dalam rangka menciptakan nuansa pitra yadnya yang dilakukan secara hidmat. Hal tersebut sesuai dengan pendapat Durkheim, 1992: 12) menjelaskan bahwa budaya melalui suatu sistem kepercayaan dapat disatukan oleh praktek-praktek yang bertalian dengan hal yang suci. Upacara ngaben di Kota Mataram pada umumnya dilengkapai dengan suara lantunan kidung, sloka, dan wirama yang merupakan bagian atau kelengkapan ritual ngaben. Hal inilah menjadi penciri bahwa upacara ngaben dapat berjalan meriah dan sakral. Dengan adanya lantunan kidung, sloka, dan wirama justru dilarang dengan alasan mengganggu kegiatan sholat. Hal inilah yang mengganggu keharmonisan, termasuk mengecewakan umat Hindu Kota Mataram.

\section{Kesimpulan}

Dari latar belakang dan pembahasan di atas, maka dapat diambil kesimpulan sebagai berikut: Fenomena Hindu dalam pelaksanaan upacara ngaben (Pitra Yadnya) di Kota Mataram adalah sebagai berikut: 1) Pelaksanaan pembuangan abu yang selalau mendapat hambatan sosial, sehingga menimbulkan kekecewaan umat Hindu dalam melaksanakan upacara Ngaben; 2) Bunyi-bunyian Anglung, Gong, dan Gender yang digunakan sebagai pelengkap dan memebrikan nilai kebersamaan, kekeluargaan, dan persatuan menjadi dianggap mengganggu umat lain dalam menjalan ibadahnya; dan 3) Penggunaan Loud Speaker Bunyi Dharma Gita yang dapat memberikan kemeriahan dan rasa estetis dalam peleksanaan ngaben dianggap mengganggu lingkungan sekitarnya. Fenomena ini memberikan pencitraan kerukunan umat beragama kurang adil, diskriminasi, dan menimbulkan ketegangan sosial masayarat, khususnya masayarakat Hindu di Kota Mataram. Hal tersebut terjadi disebabkan karena adanya dominasi kekuasaan, pemahaman agama sempit, dan kurang penghargaan tehadap nilai-nilai kelokalan. 


\section{Daftar Pustaka}

Amin, Ahmad. 1997. Adat Istiadat Daerah Nusa Tenggara Barat. Jakarta: Depdikbud. Ditjen Kebudayaan.

Arikunto, Suharsini. 2010. Prosedur Penelitian Suatu Pendekatan Praktek. Jakarta: Rineka Cipta.

Darmadi, Hamid. 2011. Metode Penelitian Pendidikan. Bandung: Alfabeta.

Digdoyo., Eko. 2015. Ilmu Sosial dan Budaya Dasar. Bogor: Ghalia Indonesia.

Durkheim, Emile. 1992. The Elementary Form of The Religious Life. New York: Free Press.

Koentjaraningrat. 2004. Kebudayaan Mentalitas dan Pembangunan. Jakarta: Gramedia Pustaka Pelajar.

Kuswarno, Engkus. 2013. Fenomenologi. Bandung: Widya Padjajaran.

Mantra, I. B. 2004. Filsafat penelitian dan Metode Penelitian Sosial. Yogyakarta: Pustaka Pelajar.

Mulyana, Dedy. 2001. Komunikasi Antarbudaya, Panduan Komunikasi dengan OrangOrang Berbeda Budaya. Bandung: PT Remaja Rosdakarya.

Sugiyono, 2005. Metode Penelitian Pendidikan, Pendekatan Kualitatif, Kuantitatif, dan $R A D)$. Bandung: Alfabeta.

Sutrisno, Mudjidi, dkk. 2005. Teori-Teori Kebudayaan. Yogyakarta: Konsensius.

Wiana, I Ketut. 2006. Sembahyang Hindu. Surabaya: Paramitha 